\title{
Public knowledge, attitude and practice on influenxa pandemic (H1N1) 2009 prevention in Southern Vietnam
}

\author{
Ho Thi Thien Ngan ${ }^{1 *}$, Tran Ngoc Huu ${ }^{1}$, Bui Thu Huong ${ }^{2}$, Nguyen Trung Nghia ${ }^{3}$, Le Van Tuan ${ }^{4}$ \\ From Institut Pasteur International Network Annual Scientific Meeting \\ Hong Kong. 22-23 November 2010
}

\section{Background}

After quickly spreading since March 2009 in Mexico, influenza pandemic H1N1 has affected a large part of the world's population. Countries have made great efforts to contain the pandemic. An important key in containing community transmission and reducing the impacts of the pandemic influenza is to have local people educated to have good knowledge, attitude and practice toward influenza pandemic (H1N1). The aim of this study was to assess knowledge, attitute and practice of local people toward influenza pandemic (H1N1) prevention after launching education programs since early pandemic period (June 2009).

\section{Methods}

During the post-peak period of influenza pandemic (H1N1) (20 March - 8 April 2010) a cross - sectional survey was conducted in $\mathrm{Cu} \mathrm{Chi}$ district of Ho Chi Minh City and Ninh Kieu district of Can Tho City. Among 304 individuals (32\% male and 68\% female) who were selected systematic randomly and representing for risk population as workers, students who living in the boarding houses, boarding schools. Outcome measures were perceived containment and prevention activities, received pandemic information. Knowledge, attitude and practice on personal and community prevention focused on hand washing, respiratory etiquette, avoidance of close contact with sick people, staying home if sick and house cleaning.

\section{Results}

83.9\% of respondents felt that the pandemic responses by the government were essential and timely. $87.5 \%$ have received the pandemic information through flyers, radio, TV spots, newspaper, and meetings. However, 63.3\% felt satisfied with the provided information. Respondents rated face-mask and hand-washing as the most effective preventive measures (97\%). The percentage of people who have good knowledge on pandemic influenza personal prevention (i.e. wash hands plus avoid close contact with sick people) was $74.7 \%$, while only $36.8 \%$ had good knowledge on community prevention (cover nose and mouth when coughing or sneezing, stay home from work or school if sick, cleaning house). Female had better knowledge on house-cleaning than male, however male had better practice than female with difference statistically significant.

\section{Conclusion}

Implementing education programs were successful and effective in raising public awareness about influenca pandemic. This proven that education measurement is one of important keys of pandemic containment strategies. Although the percentage of people having good knowledge and acceptable attitude were high, practice on community prevention among local people was still poor. Therefore, in the future education programs should focus on improving good practice for containing community transmission of influenza pandemic.

${ }^{1}$ Pasteur Institute of Ho Chi Minh City, Vietnam

Full list of author information is available at the end of the article

(c) 2011 Ngan et al; licensee BioMed Central Ltd. This is an open access article distributed under the terms of the Creative Commons Attribution License (http://creativecommons.org/licenses/by/2.0), which permits unrestricted use, distribution, and reproduction in any medium, provided the original work is properly cited. 


\section{Author details}

${ }^{1}$ Pasteur Institute of Ho Chi Minh City, Vietnam. ${ }^{2}$ Unilever, Hanoi, Vietnam.

${ }^{3}$ Preventive Medicine Center, Can Tho City, Vietnam. ${ }^{4}$ World Health

Organization, Ho Chi Minh City, Vietnam.

Published: 10 January 2011

doi:10.1186/1753-6561-5-S1-P8

Cite this article as: Ngan et al:: Public knowledge, attitude and practice on influenxa pandemic (H1N1) 2009 prevention in Southern Vietnam. BMC Proceedings 2011 5(Suppl 1):P8.

Submit your next manuscript to BioMed Central and take full advantage of:

- Convenient online submission

- Thorough peer review

- No space constraints or color figure charges

- Immediate publication on acceptance

- Inclusion in PubMed, CAS, Scopus and Google Scholar

- Research which is freely available for redistribution

Submit your manuscript at www.biomedcentral.com/submit 